Chirurgia (2020) 115: 423-431

No. 4, July - August

Copyright@ Celsius

http://dx.doi.org/10.21614/chirurgia.115.4.423

\title{
Post-Gastrectomy Complications - An Overview
}

\author{
Ray Samrat*, Mehta Naimish, Nundy Samiran \\ Surgical Gastroenterology and Liver Transplantation, Sir Ganga Ram Hospital, New Delhi, India
}

${ }^{*}$ Corresponding author:

Samrat Ray, MS, DNB (GI Surgery)

Associate consultant

Department of Surgical Gastroenterology

and Liver Transplantation, Sir Ganga Ram

Hospital, Room no. 2222

Old Rajinder Nagar, New Delhi -110060

E-mail: samrat.ray2711@gmail.com

\section{Rezumat \\ Complicatiile post-gastrectomie - o trecere în revistă}

Complicațiile post-gastrectomie sunt sechelele asociate gastrectomiei curative, care apar după un timp de la intervenție. Acestea includ simptome enigmatice, de la modificări metabolice la tulburări de natură mecanică şi neurologică după restabilirea continuității digestive. $\mathrm{Cu}$ toate că incidența complicațiilor a cunoscut un declin datorită progreselor în domeniul chirurgical şi a trecerii către managementul medical şi endoscopic al ulcerelor gastro-duodenale benigne, acestea continuă să ridice probleme după rezecțiile gastrice oncologice majore. Identificarea acestor simptome şi managementul pe baza protocoalelor au o importanță majoră în arsenalul chirurgilor, a medicilor rezidenți, specialişti şi primari.

Cuvinte cheie: gastrectomie, sindrom post-gastrectomie, reconstrucție, metabolic, rezervor

\section{Abstract}

Post-gastrectomy complications have been the associated sequelae after curative gastrectomy for long time. They include a conundrum of symptoms ranging from serious metabolic alterations to disorders attributed to mechanical and neural factors after reconstruction of the digestive continuity. Though, with the advancement in the surgical expertise and techniques and shift towards medical and endoscopic management for benign gastro-duodenal ulcer disease, there has been a decline in the incidence of these complications; they continue to raise 'red 
flags' after major oncologic gastric resections. Identification of these symptoms and protocolbased management of the same is of utmost importance in the surgical armamentarium of trainees and practicing physicians and surgeons.

Key words: gastrectomy, post-gastrectomy syndromes, reconstruction, metabolic, reservoir

\section{Introduction}

The earliest reports of complications after gastrectomy was in 1885, when Billroth described a case of bilious vomiting with epigastric discomfort subsequent to a partial gastrectomy (1). However, over the years with the advent of a more conservative approach towards peptic ulcer disease, gastric resection procedures for benign gastric disorders have shown a major decline. This together, with advances in the multimodality approach towards gastric cancer, has resulted in a nearly $20 \%$ reduction in the rates of gastric resections over the last decade (2). The increase in the number of resectional bariatric surgeries worldwide over the last decades has also witnessed a corresponding increase in the rates of post-gastrectomy complications (3) However, in the present article we will restrict our discussion to the various physiological and mechanical complications which may follow gastrectomy for benign or malignant gastric disorders. The type of reconstruction performed after gastrectomy is a major determinant of the nature and the severity of the complication encountered (Fig. 1). In a cohort of 124 patients having undergone gastrectomy over a follow up of 15 years, Loffeld reported the predominance of upper abdominal complaints in nearly $75^{-}$ $80 \%$ and symptoms suggestive of dumping syndrome in $70 \%$ of those having undergone Billroth II reconstruction (4). Contrary to this, Pedrazzani et al reported a low incidence of dumping in a cohort of 195 patients having undergone gastrectomy with Billroth II reconstruction over a 5 year follow up period, with the majority recovering within a year of surgery (5).

\section{Classification of Post-Gastrectomy Syndromes}

Post-gastrectomy syndromes are a constellation of complications secondary to the anatomical and physiological changes which may follow gastric surgery. These could be secondary to disturbances in the gastric reservoir function or vagal denervation with resultant motor dysfunction or aberrations in the reconstruction (Table 1).

The pathophysiology and salient clinical features of the post-gastrectomy syndromes are described as follows:

\section{Acute complications}

Anastomotic leaks usually manifest between

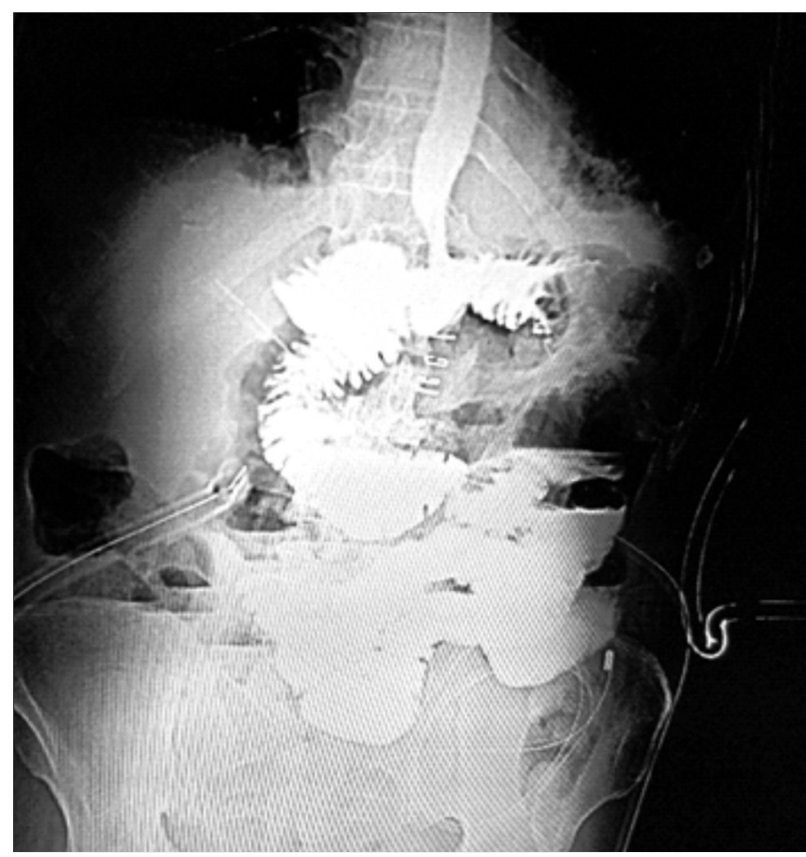

Figure 1. Barium meal study on day 5 of radical gastrectomy with Roux-en- $Y$ oesophagojejunostomy showing normal passage of contrast across the anastomosis with no leak 
Table 1. Post-gastrectomy syndromes: classification

\begin{tabular}{ll}
\hline Acute complications & - Anastomotic leak \\
& - Duodenal stump blowout \\
\hline Gastric reservoir dysfunction & - Dumping syndrome (Types I and II) \\
& - Metabolic alterations \\
\hline Vagal denervation & - Gastric stasis and hurry \\
& - Gallstones \\
\hline Aberrations of reconstruction & - Bile reflux gastritis \\
& - Afferent loop syndrome \\
& - Efferent loop syndrome \\
& - Jejunogastric intussusception \\
& - Roux stasis syndrome \\
& - Gastro-jejuno-colic fistula \\
\hline Long term complication & - Recurrent ulcerations \\
& - Remnant stump cancer \\
\hline
\end{tabular}

day 7 to day 10 of surgery (6). The source could be from the site of gastrojejunostomy (GJ) or jejuno-jejunostomy (Roux-en Y reconstructions). Owing to the high vascularity of stomach, GJ anastomotic leaks are relatively uncommon. The management of these leaks involves drainage of any localised collection in the peritoneal cavity along with antibiotics and nutritional rehabilitation (in the form of parenteral nutrition or a feeding jejunostomy).

The most feared complication after Billroth II and Roux-en Y procedures is a blowout of the duodenal stump; which usually manifests by day 4-5 of surgery. Its management involves percutaneous drainage and control of sepsis (7). Surgical intervention in the form of retrograde tube duodenostomy and addition of a feeding jejunostomy have also been described.

\section{Dumping syndrome}

This is seen in nearly $20 \%$ of the patients undergoing operations involving the pyloric sphincter (8). The two basic tenets of pathophysiology of dumping syndrome are a loss of receptive relaxation and damage to the pyloric sphincter. Subsequently, there is loss of accommodation of large volumes of solid or liquid content (9). This entity has been classified into two variants: early and late dumping. The former manifests within 30 minutes of oral intake and presents with diarrhoea, crampy abdominal pain, tachycardia, dizziness and postural hypotension.
There is probably an osmotic shift of intravascular volume secondary to the stasis of hyperosmolar contents in the gastric remnant, leading to the entire range of vasomotor symptoms. The late dumping syndrome, on the other hand, manifests $2-3$ hrs after a meal. The underlying pathophysiology is systemic hyperglycaemia, leading to activation of the GLP- 1 receptors causing excessive insulin secretion (10). This in turn causes hypoglycaemia and its associated clinical symptoms and signs such as diaphoresis, tachycardia and tachypnoea. There have been a variety of risk factors associated with the dumping syndrome. Billroth II have been found to havea higher risk of dumping symptoms compared to Billroth I reconstructions (11). Studies have also reported a higher incidence of dumping syndrome in patients with antecedent type II Diabetes Mellitus. Late dumping symptoms have also been found in as many as $70 \%$ of bariatric patients (3). In a series of 1153 patients having undergone gastrectomy, Mine et al reported a lower incidence of early dumping symptoms in older patients, in those undergoing a RouxenY reconstruction and in pylorus-preserving procedures (11). A previous history of early dumping and female gender were identified as risk factors for late dumping syndrome (12). However, studies comparing Billroth I reconstruction with Roux en Y reported no difference in the incidence of early or late dumping (13).

\section{Metabolic alterations}

The most common metabolic alterations seen after gastrectomy include anaemia (iron deficiency and B12 deficiency), bone disease and weight loss. Iron requires an acidic gastric milieu for its absorption, which is lost subsequent to a gastric resection. The ingested iron, after reduction by the gastric acid gets absorbed in the duodenum. Therefore, in postgastrectomy reconstructions bypassing the duodenum, such as the Roux en Y or Billroth II procedures, there is a lack of absorption of iron with a resultant iron deficiency state. Shiga et al, in their study of 74 patients 
having undergone gastrectomy found iron deficiency anaemia in 94\%, B12 deficiency in $79 \%$ and folate deficiency in only $4 \%$ (14). However, iron deficiency anaemia post gastrectomy merits an evaluation by upper and lower GI endoscopies before labelling it as 'nutritional'. A study by Zittel et al found the incidence of vertebral fractures and osteopenia to be as high as $55-60 \%, 5-20$ years after having undergone gastrectomy (15). The underlying pathophysiology is decreased absorption of calcium ion, owing to the loss of duodenal absorptive surface area leading to steatorrhoea and calcium precipitation in the gut lumen. A study by Melton et al revealed a 2.5 and 4.7 fold increase in the risk of distal radius, proximal femur and vertebral fractures after a median follow up of 14.8 years after gastrectomy (16). It usually starts manifesting 2-3 years after surgery and mandates immediate clinical attention. Weight loss after gastric resection usually stabilises within 3 months as a result of body's adaptive mechanism. Clinically, it is important to distinguish weight loss subsequent to gastrectomy from that as a result of malabsorption (17). There might also be micronutrient abnormalities such as copper deficiency after gastric resections. This usually manifests as ataxia and myelopathy, mimicking the vitamin B12 deficiency syndrome (18).

\section{Post vagotomy gastric stasis and hurry}

Delayed gastric emptying (DGE) is seen after truncal vagotomies, that sacrifice the nerves of Latarjet. It may also manifest after subtotal gastrectomies with food retention in the remnant stomach. Most often, the only significant symptom is epigastric fullness after oral intake, relieved by propulsive vomiting. In a study by Kubo et al, the incidence of delayed gastric emptying was found to be higher with Billroth I compared to Roux en Y or Billroth II reconstruction (19). Similar results were demonstrated by Jung et al (20). Most of the cases improve spontaneously after a few weeks. However, it is important to distinguish mechanical causes of this entity from those subsequent to vagotomy. Though, it is best recognised clinically this diagnosis may be confirmed by scintigraphic studies to assess the gastric emptying time.

Diarrhoea is seen in as many as $30 \%$ of the patients undergoing gastrectomy although it is clinically significant in around $10 \%$ of the cases (21). Damage to the coeliac branch of the vagus is a proposed mechanism. Other theories such as bile acid malabsorption and bacterial overgrowth have also been proposed (22).

\section{Gallstones}

Loss of vagal innervation to the gallbladder subsequent to damage to the hepatic branch of anterior vagus nerve leads to a state of bile stasis. This is one of the mechanisms of gallstone formation after gastrectomy. Another proposed mechanism is the loss of cholecystokinin release from the duodenum seen after bypass of the duodenum in a Roux en Y reconstruction, leading to bile stasis (23). $\mathrm{Wu}$ et al found the mean interval between gastrectomy and development of gallstones to be shorter in patients undergoing radical gastrectomy compared to the ones undergoing simple gastrectomy (24). Based on these results, they proposed prophylactic cholecystectomy in patients undergoing radical gastrectomy. The incidence of gallstone formation was reported to be higher in patients having undergone Roux en Y reconstruction compared to the ones having undergone Billroth I reconstruction (28\% vs $15 \%)(25)$.

\section{Bile reflux gastritis}

Marked unrelenting epigastric discomfort with nausea, bilious vomiting and nocturnal awakenings are the hallmarks of this entity. Consequent to long standing bile reflux, there is a profound loss of the parietal cell mass, leading to iron deficiency anaemia and weight loss. A significant decline in the incidence of bile reflux gastritis has been observed in the West (26). This is probably owing to the decline in gastrectomies for peptic ulcer disease and a higher preference of Roux en Y reconstruction by most surgeons in the West over Billroth reconstructions (27) Osugi et al 
demonstrated the highest incidence of reflux in patients undergoing Billroth II procedures $(70 \%)(28)$. In a series of 75 patients randomised into Roux en Y group vs Billroth II after distal gastrectomy with vagotomy, Csendes et al reported a better symptom profile with Roux en $\mathrm{Y}$ reconstruction, as evidenced by lower Visick scores, as well as a lower incidence of Barrett metaplasia, after a 15-year follow up (29).

\section{Afferent and efferent loop obstruction}

Afferent loop obstruction usually manifests in either of two forms: acute and chronic. The former is characterized by sudden onset severe crampy pain in the epigastrium, with nausea and non-bilious vomiting. It requires immediate surgical intervention to avoid bowel necrosis and peritonitis. The latter form manifests as epigastric fullness with copious projectile bilious vomiting 30-60 minutes after meal, leading to relief of the distension. Clinical examination may reveal visible distended bowel loops with peristalsis. Long standing chronic obstruction might even result in malabsorption and consequent bacterial overgrowth, diarrhoea and nutritional abnormalities (30). Also, lack of acid buffering in the gastric remnant might lead to a high incidence of marginal ulcerations. Various mechanisms have been postulated to cause obstruction of the afferent loop, such as kinking and angulation, adhesions, torsion and internal herniation. Imaging by CT scan reveals a dilated sentinel loop of bowel in the upper quadrant of the abdomen.

Efferent loop obstruction usually mimics proximal small bowel obstruction and is mostly caused by intra-abdominal adhesions. Other mechanisms could be herniation of the loop through mesenteric defects, that can occur in both antecolic and retrocolic locations (31).

\section{Jejuno-gastric intussusception}

First described by Bozzi in 1914 in a patient having undergone gastrojejunostomy, this is a rare but potentially serious condition seen after gastrectomy with retrocolic reconstructions (32). The intussusceptum is the efferent limb in majority of the cases. The acute form mostly presents with severe abdominal pain with persistent bloody vomiting and a palpable abdominal mass. Immediate surgical attention is needed in acute cases because amortality as high as $10-50 \%$ has been described (33).

\section{Roux stasis syndrome}

Cullen et al in 1995 had proposed the presence of cyclical electrical potentials in the small bowel, being fastest in the duodenum and spreading anterograde distally. These are called the pacesetter potentials (34). Transection of the jejunum, as seen in Roux en Y reconstruction was found to decrease the activity of these potentials in the distal bowel along with an appearance of ectopic pacemakers in the proximal Roux limb. These pacemakers trigger retrograde contractions in the proximal portion of the limb with a slowing of transit. The resultant effect of the above is difficulty in gastric emptying manifesting clinically as non-bilious vomiting, epigastric discomfort and abdominal distension. Upper GI series or CT scans are mostly inconclusive; upper GI endoscopy showing a dilated gastric remnant with afferent loop dilatation. It is usually more common in patients with a previous history of vagotomy and a large gastric remnant (>50\%) (35).

\section{Gastro-jejuno-colic fistula}

Gastro-jejuno-colic fistula (GJF) is a rare complication seen years after gastric resection followed by a gastrojejunostomy. The pathophysiology involves erosion of the gastrojejunostomy stomal ulcers into the adjacent loop of the transverse colon (36). The most frequent presentation is with faeculent vomiting, abdominal bloating and epigastric discomfort. The typical symptoms in longstanding cases are diarrhoea and weight loss against the background of a previous gastric resection, present in $80-85 \%$ of patients (37). Gastroscopy usually reveals faeculent content at the site of gastrojejunostomy. Studies by Nussinson et al recommended a combination of colonoscopy and gastroscopy for diagnosis and ruling out other disease entities (38). 
Barium enema has been found to be $95-100 \%$ sensitive in diagnosing this entity (39).

\section{Recurrent peptic ulceration}

A retained gastric antrum and incomplete vagotomy have been incriminated in the pathophysiology of recurrent peptic ulceration in the gastric remnant. The incidence is higher in Billroth II reconstructions. Owing to uncontrolled secretion of gastrin from the antral remnant the resulting hyperacidic environment promotes recurrent ulcerations. Distinguishing this from the Zollinger-Ellison syndrome as the cause of hypergastrinaemia is important. A fasting serum gastrin level along with intravenous secretin administration may distinguish the two; with the former demonstrating an elevated fasting gastrin but suppressed by secretin (40). In the absence of elevated gastrin levels, a positive sham feeding test (causing a large increase in gastric acid output compared to the baseline level) may suggest an incomplete vagotomy as the cause (41).

\section{Remnant gastric stump cancer}

Studies have described the incidence of stump cancer in the range of $0.8-9 \%$ worldwide (42). The risk is maximum $15-20$ years after the index operation. The distal stump of the stomach at the site of gastro-enteric anastomosis is the most common site (attributed to repeated longstanding exposure to biliopancreatic secretions). Another hypothesis suggested the possible role of hypochlorhydria leading to conversion of nitrates to nitrites and resultant generation of nitroso compounds adding to carcinogenesis (43). Viste et al reported a $2.5 \%$ incidence in a series of 3470 patients undergoing gastrectomy for benign pathology (44). Routine endoscopic surveillance is however not recommended and should be guided only by relevant symptoms.

\section{Management of Post-Gastrectomy Complications}

\section{Medical management}

Table 2 summarises an overview of the medical management of post-gastrectomy complications.
Table 2. Overview of medical management

\begin{tabular}{|c|c|}
\hline Dumping syndrome & $\begin{array}{l}\text {-Anti-dumping dietary measures (45): } \\
\text { - slow, frequent (6-8), small meals; } \\
\text { - eating upright; } \\
\text { - avoiding complex sugar foods like ice } \\
\text { cream, colas etc; } \\
\text { - limit fluid consumption prior to meals } \\
\text { (at least } 30-40 \text { mins); } \\
\text { - high protein, high fibre diet recommended; } \\
\text { - keep anti-hypoglycaemic measures } \\
\text { available for emergency. } \\
\text { - Octreotide/Octreotide LAR } \\
\text { (Long acting release): } \\
\text { - therapy of choice in patients refractory } \\
\text { to dietary measures (46,47); } \\
\text { - 50-100 } \mu \mathrm{g} \text { s/c } 15-45 \text { min before meals; } \\
\text { - highly efficacious (Vecht et al) (48); } \\
\text { - side effects: diarrhoea and steatorrhoea. } \\
\text {-Pectin: shown to decrease vasomotor } \\
\text { symptoms; slowing of initial gastric } \\
\text { emptying (49,50). } \\
\text { - Guar Gum: Similar action as pectin (51). } \\
\text { - Glucomannan: Significantly improved } \\
\text { Glucose tolerance; no effect on glucose } \\
\text { absorption (52). } \\
\text {-Acarbose: Competitive inhibitor of alpha- } \\
\text { glycosidase. A dose of } 50 \text { mg TDS } \\
\text { recommended for prevention of late } \\
\text { dumping symptoms (53). }\end{array}$ \\
\hline $\begin{array}{l}\text { Post vagotomy } \\
\text { diarrhoea }\end{array}$ & $\begin{array}{l}\text { - Cholestyramine: Owing to the bile acid } \\
\text { malabsorption hypothesis, it might be } \\
\text { theoretically efficacious (54). }\end{array}$ \\
\hline $\begin{array}{l}\text { Gastric stasis/ } \\
\text { Gastroparesis }\end{array}$ & $\begin{array}{l}\text { - Prokinetics: Metoclopramide, } \\
\text { Levosulpiride, Erythromycin; Some role in } \\
\text { early post-operative gastric atony. } \\
\text { - Monitoring for development of Baezoars. }\end{array}$ \\
\hline $\begin{array}{l}\text { Nutritional/ } \\
\text { Metabolic alterations }\end{array}$ & $\begin{array}{l}\text {-Vitamin B12: Inj Cyanocobalamin } \\
\text { supplementation at } 3 \text { monthly intervals } \\
\text { recommended (55). } \\
\text { - Metabolic bone disease: } 500 \text { mg Calcium } \\
\text { TDS; } 800 \text { IU vitamin D daily recommended; } \\
56 \text { monitoring by DEXA scan. } \\
\text { - Treat bacterial overgrowth by appropriate } \\
\text { broad-spectrum antibiotics }\end{array}$ \\
\hline
\end{tabular}

\section{Surgical management}

In cases refractory to medical measures, surgery is the mainstay of treatment. Overall, $<5 \%$ patients have been found to merit repeated surgery. In the complications related to the reconstruction, surgery remains the treatment of choice.

Table 3 summarises the available surgical options for post-gastrectomy complications. 
Table 3. Summary of surgical options

\begin{tabular}{|c|c|}
\hline Dumping syndrome & $\begin{array}{l}\text { - Interposition of jejunal loop: Iso/ } \\
\text { anti-peristaltic. } \\
\text { - Conversion of loop gastrojejunostomy to } \\
\text { RouxenY reconstruction }(57,58) \text {. }\end{array}$ \\
\hline $\begin{array}{l}\text { Post vagotomy } \\
\text { diarrhoea }\end{array}$ & $\begin{array}{l}\text { - Anti-peristaltic jejunal loop distal } \\
\text { interposition (59). }\end{array}$ \\
\hline Gastric stasis & $\begin{array}{l}\text { - Gastric pacing/Electric pacemaker (60). } \\
\text { - Venting gastrostomy. } \\
\text { - Re-operative near total gastrectomy. }\end{array}$ \\
\hline Bile reflux gastritis & - Conversion to a Roux-en-Y reconstruction. \\
\hline $\begin{array}{l}\text { Afferent loop } \\
\text { syndrome and } \\
\text { Efferent loop syndrome }\end{array}$ & $\begin{array}{l}\text { - Endoscopic insertion of double pigtail } \\
\text { stent (61). } \\
\text { - Conversion to RouxenY. } \\
\text { - Conversion to Billroth I. } \\
\text { - Braun entero-enterostomy. }\end{array}$ \\
\hline $\begin{array}{l}\text { Jejuno-gastric } \\
\text { intussusception }\end{array}$ & $\begin{array}{l}\text { - Revision of the GJ/Resection of the } \\
\text { intussuscepted segment. } \\
\text { - Revision of the GJ/Resection of the } \\
\text { Conversion to a Rouxen Y. }\end{array}$ \\
\hline Roux stasis syndrome & $\begin{array}{l}\text { - Resection followed by RouxenY revision. } \\
\text { - Avoid Roux reconstruction in >50\% } \\
\text { resection of stomach (Bll with Braun } \\
\text { entero-enterostomy preferred) (62). }\end{array}$ \\
\hline $\begin{array}{l}\text { Gastro-jejuno-colic } \\
\text { fistula }\end{array}$ & $\begin{array}{l}\text { - 3-staged procedure: colostomy (I), fistula } \\
\text { resection (II) and colostomy closure (III). } \\
\text { - 2-staged (Lahey's) procedure (63): } \\
\text { lleosigmoidostomy (I) followed by fistula } \\
\text { resection, subtotal gastrectomy and } \\
\text { colectomy (II). } \\
\text { - Laparoscopic/open one staged procedure. }\end{array}$ \\
\hline
\end{tabular}

Ishikawa et al from Japan had advocated segmental gastrectomy (preserving the pyloric sphincter) for mid-body gastric cancers; shown to increase the incidence of dumping significantly (64). However, preservation of the pyloric sphincter in a gastric remnant with a decreased capacity was shown to increase oesophageal reflux episodes. The jejunal loop interposition technique is another option for dumping syndrome. However, in a study by Nakane et al, it was found to be associated with a higher incidence of bile reflux gastritis and delayed gastric emptying (65). The antiperistaltic method might be theoretically more efficacious but is condemned by many surgeons due to the possibility of mesenteric torsion.
Billroth I vs Billroth II vs Roux-en-Y: Impact on the Quality of Life (QoL):

In a retrospective non-randomised comparison between the three forms of reconstruction, Schweizer et al reported a better Visick grading (reflux), lower incidence of dumping, bile reflux, afferent and efferent loop obstruction and a superior QoL $(p<0.001)$ with Roux-en-Y reconstruction (66). Nunobe et al retrospectively compared Billroth I and Roux-en-Y over a 5 year period and reported overall superior QoL with Rouxen-Y but also higher incidence of gallstones with the latter (12).

\section{Pouch or No Pouch for reconstruction?}

The construction of a jejunal pouch as a substitute for the stomach was proposed in 1952 by Hunt (the Hunt-Lawrence J pouch). Most RCTs have reported an overall better outcome with the addition of a pouch (67-69). Many variations have been proposed to the classic Hunt-Lawrence pouch, which include the distal pouch reconstruction, pouch interposition and S-pouch reconstruction. The gastrointestinal QoL as assessed by Visick scoring and the incidence of dumping was found better in the patients undergoing a pouch. However, there has been no difference in the outcomes demonstrated between the different variations of pouch reconstruction (70).

\section{What is New?}

In the current era, owing to the shift in management of peptic ulcer disease towards the medical arm, there has been a drastic reduction in the incidence of post-gastrectomy complications described above. However, the nature of the complications seen have shifted more towards the ones seen after bariatric surgeries, that are performed more commonly in the surgical practice in the current era. These complications mostly include leaks, bleeding and venous thromboembolism in the early phase and balloon related complications like gastric/enteric necrosis and slippage etc associated with the endoscopic bariatric 
procedures. Malabsorptive procedures like the Roux en Y Gastric bypass (RYGB) and Mini gastric bypass (MGB) come with their own set of unique complications including gallstones, marginal ulceration, internal herniation (Stammer and Petersen's hernias) and nutritional imbalances like micro-nutrient deficiencies. Studies in the recent times have analysed the background factors that might affect the outcome of gastric resections procedures. Kinami et al analysed a cohort of 2368 patients and studied the main outcome measures (MOMs) following Distal gastrectomy (DG) vs Pylorus preserving gastrectomy (PPG) vs Total Gastrectomy (TG) vs Local gastric resection. Factors such as female sex, open approach of surgery and sacrifice of coeliac nerve were identified as independent factors affecting the outcome of these gastric resection procedures (71).

\section{Conclusion}

Owing to the shift in the management of peptic ulcer disease towards the drug treatment, there has been a drastic reduction in the incidence of post-gastrectomy complications. Despite that, this constellation of postoperative complications merit attention and a protocol-based approach for management. With more innovative techniques aiming at preserving as much functional gastric remnant as possible, there is expected to be further reduction in the incidence of these complications in the decades ahead.

\section{Conflict of Interest}

The authors declare no conflicts of interests.

\section{References}

1. Ritchie WP Jr, Perez AR. Postgastrectomy syndromes. In: Moody FG, Carey LC, Jones RS, et al, editors. Surgical treatment of digestive disease. Chicago: Year Book Medical Publishers; 1986. p. 264-73.

2. Bardhan KD, Royston C. Time, change and peptic ulcer disease in Rotherham,UK. Dig Liver Dis. 2008;40:540-6.

3. Livingston $\mathrm{EH}$. The incidence of bariatric surgery has plateaued in the U.S. Am J Surg. 2010;200:378-85.

4. Loffeld RJ. Prevalence of upper abdominal complaints in patients who haveundergone partial gastrectomy. Can J Gastroenterol. 2000;14:681-4.
5. Pedrazzani C, Marrelli D, Rampone B, De Stefano A, Corso G, Fotia $G$, et al. Postoperative complications andfunctional results after subtotal gastrectomy with Billroth II reconstruction for primary gastric cancer. Dig Dis Sci. 2007;52:1757-63.

6. Woodfield CA, Levine MS. The postoperative stomach. Eur J Radiol. 2005;53-341.

7. Zivic EJ. Duodenal stump blow-out in the Billroth II gastric resection. J Natl Med Assoc. 1969;61:17-9.

8. Le Blanc-Louvry I, Savoye G, Maillot C, Denis P. Ducrotte P. An impaired accommodation of theproximal stomach to a meal is associated with symptoms after distal gastrectomy. Am J Gastroenterol. 2003:98:2642-7.

9. Ukleja A. Dumping syndrome: pathophysiology and treatment. Nutr Clin Pract. 2005:20:517-25.

10. Yamamoto H, Mori T, Tsuchihashi H, Akabori H, Naito H, Tani T. A possible role of GLP-1 in the pathophysiologyof early dumping syndrome. Dig Dis Sci. 2005;50:2263-7.

11. Mine S, Sano T, Tsutsumi K. Large-scale investigation into dumping syndrome after gastrectomy for gastric cancer. J Am Coll Surg. 2010;211:628-36.

12. Nunobe $S$, Okaro A, Sasako M, Saka M, Fukagawa T, Katai H, et al. Billroth 1 versus Roux-en-Y reconstructions: a quality-of-life survey at 5 years. Int J Clin Oncol. 2007:12:433-9.

13. Kojima K, Yamada H, Inokuchi M. A comparison of Roux-en-Y and Billroth-I reconstruction after laparoscopy-assisted distal gastrectomy. Ann Surg. 2008;247:962-7.

14. Shiga K, Nishimukai M, Tomita F, Hara H. Ingestion of difructose anhydride III, a nondigestibledisaccharide, prevents gastrectomyinduced iron malabsorption and anemia in rats. Nutrition. 2006:22:786-93

15. Zittel TT, Zeeb B, Maier GW, Kaiser GW, Zwirner M, Liebich H, et al. High prevalence of bone disorders aftergastrectomy. Am J Surg. 1997:174:431-8.

16. Melton LJ 3rd, Crowson CS, Khosla S, O'Fallon WM. Fracture risk after surgery for pepticulcer disease: a population-based cohort study. Bone. 1999;25:61-7.

17. Beyan C, Beyan E, Kaptan K, Ifran A, Uzar Al. Post-gastrectomy anemia: evaluation of 72cases with post-gastrectomy anemia. Hematology. 2007;12:81-4.

18. Tan JC, Burns DL, Jones HR. Severe ataxia, myelopathy, and peripheral neuropathydue to acquired copper deficiency in a patient with history of gastrectomy.J Parenter Enteral Nutr. 2006 30:446-50

19. Kubo M, Sasako M, Gotoda T, Ono H, Fujishiro M, Saito D, et al Endoscopic evaluation of the remnantstomach after gastrectomy: proposal for a new classification. Gastric Cancer. 2002;5:83-9.

20. Jung HJ, Lee JH, Ryu KW, Lee JY, Kim CG, Choi IJ, et al. The influence of reconstruction methods on foodretention phenomenon in the remnant stomach after a subtotal gastrectomy. J Surg Oncol. 2008;98:11-4.

21. Mochiki E, Asao T, Kuwano H. Gastrointestinal motility after digestive surgery. Surg Today. 2007;37:1023-32.

22. Borbely YM, Osterwalder A, Kroll D, Nett PC, Inglin RA. Diarrhoea after bariatric procedures: Diagnosis and therapy. World $\mathrm{J}$ Gastroenterol. 2017;23:4689-700.

23. Liang TJ, Liu SI, Chen YC, Chang PM, Huang WC, Chang HT, et al. Analysis of gallstone disease after gastric cancer surgery. Gastric Cancer.2017:20:895-903.

24. Wu CC, Chen CY, Wu TC, Liu TJ, P'eng PK. Cholelithiasis and cholecystitis after gastrectomyfor gastric carcinoma: a comparison of lymphadenectomy of varying extent. Hepatogastroenterology. 1995;42:867-72.

25. Bernini M, Bencini L, Sacchetti R, Marchet A, Cristadoro L, Pacell $\mathrm{F}$, et al. The Cholegas study: safety of prophylactic cholecystectomy during gastrectomy for cancer: preliminary results of a multicentric randomized clinical trial. Gastric Cancer. 2013;16:370-6.

26. Fukuhara $K$, Osugi $H$, Takada N, Takemura M, Higashino M, Kinoshita $\mathrm{H}$, et al. Reconstructive procedure after distal gastrectomy for gastric cancer that best prevents duodenogastro- 
esophageal reflux. World J Surg. 2002;26:1452-7.

27. Namikawa T, Kitagawa H, Okabayashi T, Sugimoto T, Kobayashi M, Hanazaki K. Roux-en-Y reconstruction is superiorto Billroth reconstruction in reducing reflux esophagitis after distal gastrectomy: special relationship with the angle of His. World $\mathrm{J}$ Surg. 2010;34:1022-7.

28. Osugi $H$, Fukuhara $K$, Takada N, Takemura M, Kinoshita $H$. Reconstructive procedure after distalgastrectomy to prevent remnant gastritis. Hepatogastroenterology. 2004:51:1215-8.

29. Csendes A, Burgos AM, Smok G, Burdiles P, Braghetto I, Diaz JC Latest results (12-21 years) of a prospectiverandomized study comparing Billroth II and Roux-en-Y anastomosis after a partial gastrectomy plus vagotomy in patients with duodenal ulcers. Ann Surg. 2009;249:189-94.

30. Bushkin FL, Woodward ER. The afferent loop syndrome. Major Probl Clin Surg. 1976;20:34-48.

31. Sukumar N, Shukri J, Jegan T, Tee SS. An unusual cause of efferent loop obstruction. Med J Malaysia. 2002;57:221-224.

32. Bozzi E: Annotation. Bull Acad Med. 1914; 122: 3-4.

33. Shackman R.Jejunogastric intussusception. $\mathrm{Br} J$ Surg. 1940;27:475-80.

34. Cullen JJ, Eagon JC, Hould FS, Hanson RB, Kelly KA. Ectopic jejunal pacemakers after jejunaltransection and their relationship to transit. Am J Physiol. 1995;268:G959-67.

35. Miedema BW, Kelly KA, Camilleri M, Hanson RB, Zinsmeister AR, O'Connor MK, et al. Human gastric and jejunal transit and motility after Roux gastrojejunostomy. Gastroenterology 1992;103:1133-43.

36. Joyce TM, Rosenblatt MS.Gastrojejunocolic fistula following gastrectomy. Ann Surg. 1946;124:142-5.

37. Marshall SF, Knud-Hansen J.Gastrojejunocolic and gastrocolic fistulas. AnnSurg. 1957;145:770-82.

38. Nussinson E, Samara M, Abud H. Gastrojejunocolic fistula diagnosed bysimultaneous gastroscopy and colonoscopy. Gastrointest Endosc. 1987;33:398-9.

39. Thoeny RH, Hodgson JR, Scudamore HH. The roentgenologic diagnosis ofgastrocolic and gastrojejunocolic fistulas. Am J Roentgenol Radium TherNucl Med. 1960;83:876-81.

40. Turnage RH, Sarosi G, Cryer B,Spechler S, Peterson W, Feldman M, et al. Evaluation and management of patients withrecurrent peptic ulcer disease after acid-reducing operations: a systematicreview. J Gastrointest Surg. 2003;7:606-26.

41. Ingvar C, Adami HO, Enander LK, Enskog L, Rydberg B. Clinical results of reoperation after failedhighly selective vagotomy. Am J Surg. 1986;152:308-12.

42. Helsingen N, Hillestad L. Cancer development in the gastric stump after partialgastrectomy for ulcer. Ann Surg. 1956;143:173-9.

43. Fischer $A B$, Graem N, Jensen OM. Risk of gastric cancer after Billroth II resectionfor duodenal ulcer. Br J Surg. 1983;70:552-4.

44. Viste A, Opheim P, Thunold J, Eide GE, Bjørnestad E,Skarstein A, et al. Risk of carcinoma following gastric operationsfor benign disease. A historical cohort study of 3470 patients. Lancet. 1986; 2:502-5.

45. Braga M, Zuliani W, Foppa L. Food Intake and nutritionalstatus after total gastrectomy: results of a nutritional follow-up.Br J Surg, 1988;75:477-80.

46. Didden P, Penning C, Masclee AA. Octreotide therapy indumping syndrome: Analysis of long-term results. Aliment Pharmacol Ther. 2006:24:1367-75

47. Hasler WL, Soudah HC, Owyang C. Mechanisms by whichoctreotide ameliorates symptoms in the dumping syndrome. JPharmacol Exp Ther. 1996;277:1359-65.

48. Vecht J, Lamers CB, Masclee AA. Long-term results ofoctreotidetherapy in severe dumping syndrome. Clin Endocrinol(Oxf). 1999; 51:619-24.

49. Lawaetz O, Blackburn AM, Bloom SR, Aritas Y, Ralphs DN.Effect of pectin on gastric emptying and gut hormone release inthe dumping syndrome. Scand J Gastroenterol.1983;18:327-36.

50. Leeds AR, Ralphs DN, Ebied F, Metz G, Dilawari JB. Pectin inthe dumping syndrome: reduction of symptoms and plasma volumechanges. Lancet.1981;1:1075-8.

51. Harju E, Heikkila J, Larmi TK. Effect of guar gum on gastricemptying after gastric resection.J Parenter Enteral Nutr.1984;8:18-20.

52. Kneepkens CM, Fernandes J, Vonk RJ. Dumping syndrome inchildren. Diagnosis and effect of glucomannan on glucose toleranceand absorption. Acta Paediatr Scand.1988:77:279-86.

53. De Cunto A, Barbi E, Minen F, Ventura A. Safety and efficacy of highdose acarbose treatment for dumping syndrome. J PediatrGastroenterol Nutr.2011;53:113-4.

54. Condon JR, Robinson V, Suleman MI, Fan VS, McKeown MD. The cause and treatment of postvagotomy diarrhoea. $\mathrm{Br} J$ Surg. 1975;62:309-12

55. Slot WB, Merkus FW, Van Deventer SJ. Normalization ofplasma vitamin B12 concentration by intranasal hydroxocobalaminin vitamin B12-deficient patients. Gastroenterology.1997;113:430-3.

56. Arden NK, Cooper C. Assessment of the risk of fracture inpatients with gastrointestinal disease. Eur JGastroenterolHepatol. 2003:15:865-8

57. Richards WO, Golzarian J, Wasudev N, Sawyers JL. Reverse phasic contractions arepresent in antiperistaltic jejunal limbs up to twenty-one years postoperatively.J Am Coll Surg. 1994;178:55763.

58. Sawyers JL, Herrington JL. Superiority of antiperistaltic jejunal segments inmanagement of severe dumping syndrome. Ann Surg. 1973;178:311-9.

59. Herrington JL Jr, Edwards WH, Carter JH, Sawyers JL. Treatment of severe postvagotomy diarrhoea by reversed jejunal segment. Ann Surg. 1968;168:522-41

60. Forster J, Saroseik I, Delcore R, Lin Z, Raju GS, McCallum RW. Gastric pacing is a new surgical treatment for gastroparesis. Am J Surg. 2001;182:676-81.

61. Lee WY, Moon JS. Endoscopic treatment of efferent loop syndrome with insertion of double pigtail stent. World J Gastroenterol. 2013:19:7209-12.

62. Tu BLN, Kelly KA. Surgical treatment of Roux stasis syndrome. J Gastrointest Surg. 1999:3:613-7.

63. Lahey FH: Diagnosis and management of gastrojejunal ulcer andgastrojejunocolic fistula. Arch Surg. 1941;43:850-7.

64. Ishikawa M, Kitayama J, Kaizaki S, Nakayama H, Ishigami H, Fuji S, et al. Prospective randomized trial comparingBillroth I and Rouxen-Y procedures after distal gastrectomy for gastric carcinoma.World J Surg. 2005;29:1415-20.

65. Nakane Y, Okumura S, Akehira K, Okamura S, Boku T, Okusa T, et al. Jejunal pouch reconstruction after totalgastrectomy for cancer. A randomized controlled trial. Ann Surg. 1995;222:27-35.

66. Schweizer W, Blunschi T, Seiler C. Postgastrectomy symptoms after partialstomach resection: Billroth I vs. Billroth II vs. reconstruction with roux-Y-Ioop. HelvChir Acta. 1994:60:665-9.

67. livonen MK, Mattila JJ, Nordback IH, Matikainen MJ. Long-term follow-up of patients withjejunal pouch reconstruction after total gastrectomy. A randomized prospective study. Scand J Gastroenterol. 2000;35:679-85.

68. Fein M, Fuchs KH, Thalheimer A,Freys SM, Heimbucher J, Thiede A. Long-term benefits of Roux-en-Y pouchreconstruction after total gastrectomy: a randomized trial. Ann Surg. 2008;247:759-65.

69. Zhang JZ, Lu HS, Wu XY, Huang CM, Wang C, Guan GX, et al. Influence of different procedures of alimentarytract reconstruction after total gastrectomy for gastric cancer on the nutritionand metabolism of patients: a prospective clinical study. Zhonghua Yi Xue ZaZhi. 2003;83:1475-8. [In Chinese]

70. Svedlund J, Sullivan M, Liedman B, Lundell L. Long term consequences of gastrectomyfor patient's quality of life: the impact of reconstructive techniques. Am J Gastroenterol. 1999;94:438-45.

71. Kinami S, Takahashi $M$, Urushihara $T$, Ikeda M, Yoshida M, Uenosono $\mathrm{Y}$, et al. Background factors affecting postgastrectomy syndromes after various types of gastrectomy. World J Clin Cases. 2018:6:1111-20. 